\title{
Commentary
}

\section{Basosquamous Carcinoma: A Commentary}

\author{
Christina Fotiadou *, Zoe Apalla (1) and Elizabeth Lazaridou (1)
}

check for

updates

Citation: Fotiadou, C.; Apalla, Z.; Lazaridou, E. Basosquamous Carcinoma: A Commentary. Cancers 2021, 13, 6146. https://doi.org/ 10.3390/cancers 13236146

Academic Editors: Philip R. Cohen and Karl D. Lewis

Received: 19 October 2021

Accepted: 4 December 2021

Published: 6 December 2021

Publisher's Note: MDPI stays neutral with regard to jurisdictional claims in published maps and institutional affiliations.

Copyright: (c) 2021 by the authors. Licensee MDPI, Basel, Switzerland. This article is an open access article distributed under the terms and conditions of the Creative Commons Attribution (CC BY) license (https:// creativecommons.org/licenses/by/ $4.0 /)$.
Second Department of Dermatology_-Venereology, Aristotle University, Medical School, 54124 Thessaloniki, Greece; zapalla@auth.gr (Z.A.); bethlaz@auth.gr (E.L.)

* Correspondence: cifotiad@auth.gr; Tel.: +30-2410553993

Simple Summary: Basosquamous carcinoma is a rare, aggressive non-melanoma skin cancer with features that lie between those of basal cell carcinoma and squamous cell carcinoma. A lot of controversy has been raised around the classification, pathogenesis, histologic morphology, biologic behavior, prognosis and management of this tumor. This is a narrative review based on articles published on PubMed in English language which had in their title the terms "basosquamous carcinoma" and/or "metatypical carcinoma of the skin". The aim of this review was to summarize and evaluate the latest data of the English literature regarding epidemiology, clinical presentation, dermoscopic and histopathologic characteristics, as well as the genetics and management of BSC to better characterize basosquamous skin lesions.

Abstract: Basosquamous carcinoma is a rare, aggressive non-melanoma skin cancer with features that lie between those of basal cell carcinoma and squamous cell carcinoma. A lot of controversy has been raised around the classification, pathogenesis, histologic morphology, biologic behavior, prognosis and management of this tumor. This is a narrative review based on an electronic search of articles published in PubMed in English language which had in their title the terms "basosquamous carcinoma" and/or "metatypical carcinoma of the skin". The aim of this review was to summarize and evaluate current data regarding epidemiology, clinical presentation, dermoscopic and histopathologic characteristics, as well as the genetics and management of BSC, in order to shed some more light onto this intriguing entity. As a conclusion, dermoscopy, deep incisional biopsies and immunohistologic techniques (Ber-EP4) should be applied in clinically suspicious lesions in order to achieve an early diagnosis and better prognosis of this tumor. Surgical treatments, including wide excision and Mohs' micrographic surgery, remain the treatment of choice. Finally, vismodegib, a Hedgehog pathway inhibitor, must be thoroughly investigated, with large controlled trials, since it may offer an alternative solution to irresectable or difficult-to-treat, locally advanced cases of basosquamous carcinoma.

Keywords: basosquamous carcinoma; metatypical basal cell carcinoma; diagnosis; treatment; biologic behavior; dermoscopy; histopathology; Mohs' micrographic surgery; genetics; vismodegib

\section{Introduction}

Basosquamous carcinoma (BSC) is a rare, relatively aggressive non-melanoma skin tumor which has raised a lot of controversy regarding its classification, its pathogenesis and its management since it was first described in the early 20th century. Multiple diagnostic and treatment challenges arise from the fact that BSC has a variable and non-characteristic clinical and histologic morphology seated between that of basal cell carcinoma (BCC) and squamous cell carcinoma (SCC) that is followed by a rather unpredictable biologic behavior.

This article aimed to summarize and evaluate all the latest data of the English language literature regarding epidemiology, clinical presentation, dermoscopic and histopathologic characteristics, as well as the genetics and management of BSC, in order to shed some more light to this intriguing entity. 


\section{Materials and Methods}

A PubMed search of articles in English was conducted using the term BSC and/or metatypical BCC alone or with the following subheadings: classification, incidence, epidemiology, diagnosis, histopathology, dermoscopy, genetics, biologic behavior, treatment.

Inclusion criteria were: (1) case series or case reports of BSC; and (2) review articles, meta-analyses and systematic reviews on BSC;

Exclusion criteria were: (1) articles in a language other than English (i.e., French, German, Spanish, Chinese, etc.); and (2) articles about BSC of organs other than the skin (i.e., larynx, nasopharynx, lungs, anus, etc.);

Additionally, selected articles that were referenced in the included publications were used to support the discussion of our review.

\section{Results}

\subsection{Background and Definition}

The very first description of this tumor was made by Beadles back in 1894 and it was considered a type of rodent ulcer [1,2]. He described a lesion with features both of BCC and SCC which could not be clearly separated [1,2]. Again, in 1910, in a larger series of rodent ulcers, McCormack wrote about tumors with intermixed basaloid and squamous features [2,3]. For the first time, in 1928, the term BSC was used by Montgomery in order to describe 17 out of 119 carcinomas which he believed were transitional between basal and squamous cell carcinomas $[4,5]$.

In the following years, the origin and the definition of this entity troubled pathologists [6,7]. Some of them considered these lesions as collisions of separate primary BCC and SCCs, or variants of BCC that form keratin while others believed them to be independent tumors with features of both BCC and SCC $[2,8,9]$. Meanwhile, in part of the literature, BSC were referred to as "metatypical carcinomas" [5,10,11].

In more recent years, the theory of summarization is gaining ground [12]. According to this, the BSC is derived from a BCC with genetic alterations that undergo squamous differentiation $[7,11,12]$. This theory is reflected in the most recent definition of BSC by World Health Organization (WHO) in the textbook "WHO classification of skin tumors" which stated that: "Basosquamous carcinoma is a term used to describe basal cell carcinomas that are associated with squamous differentiation" [13]. At the same time, the National Comprehensive Cancer Network (NCCN) states that basosquamous carcinomas have a metastatic capacity that is more similar to that of SCC than BCC $[5,7,14]$.

\subsection{Epidemiology}

BCCs and SCCs are the most common non-melanoma skin cancers with a rising incidence in the general population, while BSC is considered a relatively rare entity [7]. Up to date, very few small studies have evaluated the specific epidemiologic characteristics of BSC $[5,6,15]$. According to previous review papers, the incidence of BSC ranges from 1.7 to $2.7 \%[5]$.

Indeed, Shuller et al. reported a BSC incidence of $1.2 \%$, Martin et al. reported a BSC incidence of $1.4 \%$ while Bowman et al.-in a retrospective study of cases treated with Moh's micrographic surgery-found an incidence of $2.7 \%[6,16,17]$. A newer retrospective study by Ciążyńska et al. revealed 180 lesions of BSC during a period of 20 years (1999-2019) which corresponded to $2.1 \%$ of all non-melanoma skin cancers (NMSCs) [7]. However, Gualdi et al., in a prospective study (2012-2015) which included 6042 NMSCs, reported a rate of $4.8 \%$ for BSCs, a percentage considerably higher than ever before [15].

\subsection{Clinical and Demographic Characteristics}

The clinical presentation of BSC is nonspecific and it does not present particular differences as compared to a common BCC (Figure 1a) [5,7]. The most common clinical scenario in BSC is a long-standing nodule that gradually becomes ulcerated. A similar clinical course was also described for metastatic BCCs $[2,7,18]$. Sun-exposed areas of the 
head and neck (82-97\%), especially the perinasal area and ears, are the most frequent anatomic locations of this tumor [2,5-7,17-19]. However, though relatively fewer, BSCs were also observed in the trunk and extremities [2,5-7,17-19].

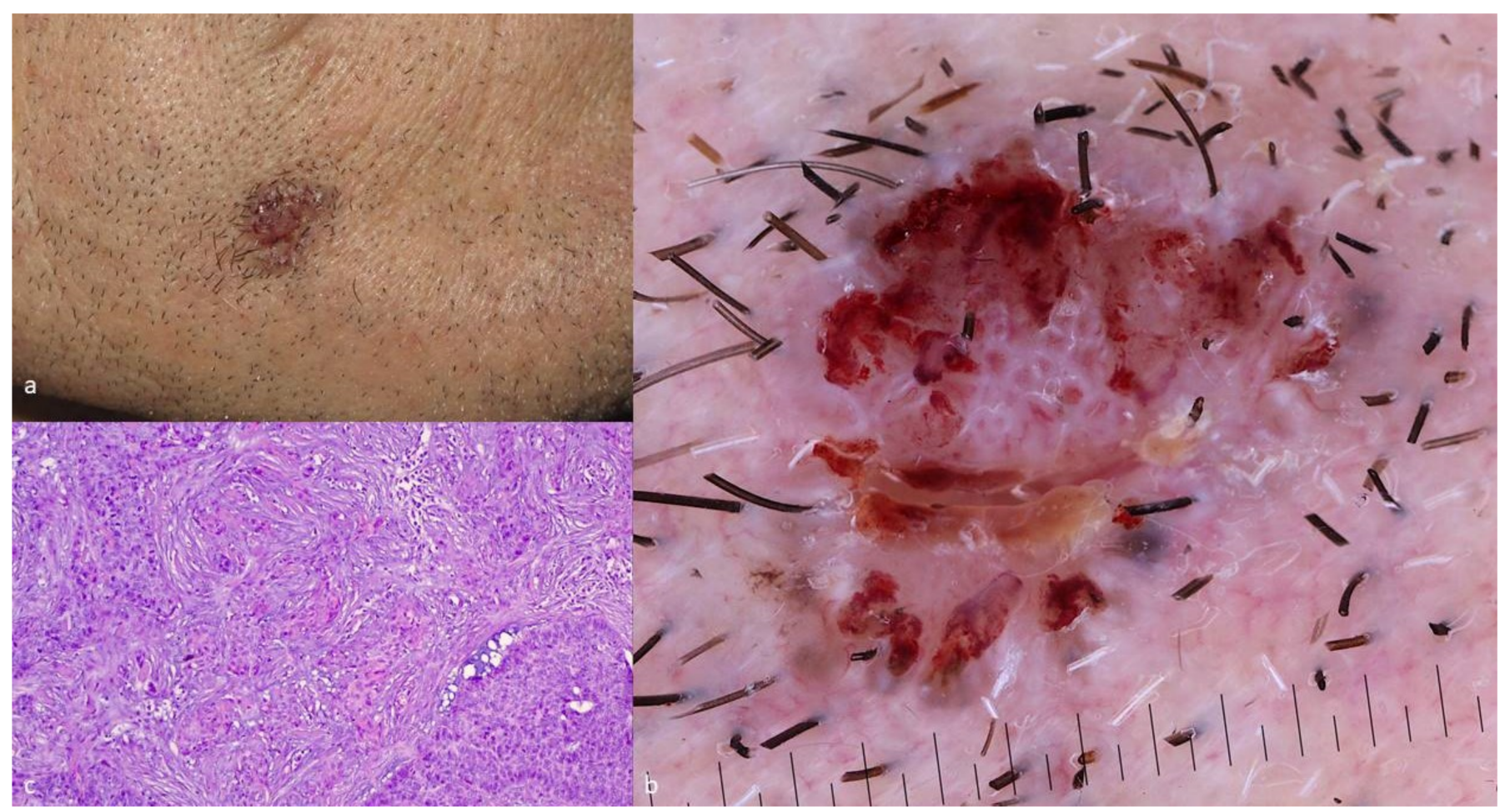

Figure 1. (a) Clinical image of a BSC; (b) dermoscopic image of a BSC revealing both a blue-grey ovoid nest and white circles; and (c) histologic image of a BSC (hematoxylin-eosin, $10 \times$ ).

Fitzpatrick type I-II and high UVR exposure are considered potent risk factors for the development of a BSC [11]. The tumor usually develops in elderly individuals (34.4\% of all BSCs are found in patients over 70 years of age) with a strong male preponderance $[6,12,15,17]$.

\subsection{Diagnosis of Basosquamous Carcinoma}

The early and concise diagnosis of this tumor is crucial due to its potentially aggressive biologic behavior. However, it is a rather intriguing task because there is an absence of a standardized diagnosing protocol. The differential diagnosis may include entities such as viral wart, seborrheic keratosis (SK), hyperkeratotic actinic keratosis (AK), Bowen's disease (BD), BCC, invasive SCC, as well as amelanotic/hypomelanotic melanoma (AHM) $[6,17,20,21]$.

\subsubsection{Dermoscopy of BSC}

Dermoscopy reveals features unrecognizable during naked-eye clinical examination and it is recommended for the early recognition of skin cancer. In this context, dermoscopy may raise the suspicion of BSC by the recognition of certain dermoscopic characteristics, seen in both types of differentiation, namely basaloid and squamoid (Figure 1b).

Unfortunately, due to the rarity of this entity, very few studies evaluating the dermoscopic features of BSC have been conducted until now [22,23]. In a study by Giacomel et al., the dermoscopic pattern of BSCs was characterized by features of both BCCs and SCCs, mirroring its complicated mixed histopathology [22]. In detail, the commonest dermoscopic criteria for BSCs were unfocused arborizing vessels, keratin masses, white structureless areas, scale, ulceration or blood crusts, white structures, blue-grey blotches and blood spots in keratin masses [22]. Finally, according to the authors, the most im- 
portant dermoscopic clue that should raise suspicion for a possible BSC diagnosis is the simultaneous presence of at least one feature of both invasive SCC and BCC [22]. The study of Acay et al., in 2017, also demonstrated that BSC is dermoscopically characterized by BCC-related polymorphous or monomorphous vasculature, combined with findings of keratinization [23]. Specifically, a serpentine of branched vessels was the most common vascular finding while keratin masses, ulceration, and white structureless areas were the most common non-vascular features [23].

\subsubsection{Histopathologic Features of BSC}

Biopsy and histologic examination remain the gold standard diagnostic method for BSC (Figure 1c). The majority of the published literature on the subject, mostly including case series, retrospective studies, and review articles, describe the presence of both BCC and SCC histologic characteristics with a transition zone between them. However, there is a certain controversy regarding how these features are arranged within the lesions $[2,5,11]$. The transition zone is considered, by most authors, as a tissue which depicts a transitional stage of differentiation between BCC and SCC cells and not simply an area with atypical BCC cells $[2,5,24]$. The BCC component of a BSC usually contains basaloid cells with a small cytoplasm and large, uniform, pale, nuclei, whilst the SCC element consists of accumulations of polygonal squamous cells containing voluminous eosinophilic cytoplasm, larger open nuclei with prominent nucleoli and frequent mitosis [2,17,24,25]. These aggregates of squamoid cells are either found inside the basaloid islands or as the other authors describe, adjacent to them $[2,5,23,24,26,27]$. Two entities that may mimic and should be considered in the histologic differential diagnosis of BSC are a collision tumor and a keratinizing BCC. In the former case, the BCC and SCC areas are completely separated with no transition zone and in the latter case, there is abrupt keratinization in the center of a nodular BCC lesion without the intervening areas of squamoid cells $[1,2,28]$. Finally, the correct histologic diagnosis of a BSC can be jeopardized when the biopsy is superficial and not incisional. In this scenario, the lack of deep areas of the lesion in the sample, where the squamoid characteristics often lay, may result in the incorrect interpretation of the tumor as a classic BCC [1,2].

\subsubsection{Immunohistologic Features of BSC}

The histologic diagnosis of a BSC may be strengthened by the application of an immunohistochemical criterion such as human epithelial antigen (HEA) expression [20]. Despite the fact that no specific immunohistologic marker for BSCs exists, the Ber-EP4, an anti-HEA mouse monoclonal antibody, which is usually strongly positive in BCCs and the epithelial membrane antigen (EMA), which stains positive in SCCs, have proved to be helpful [2]. In a "typical" BSC, the BCC element is Ber-EP4, cytokeratin (AE1) and cytokeratin (AE3) positive, whereas the area of SCC is AE1, AE3, and CAM5.2 positive with variable staining for EMA $[2,5,18]$. Moreover, the transition zone, though not always present, is typically characterized by a gradual decline in Ber-EP4 staining as an indication of transitioning from the area of the basaloid to the area of squamous differentiation $[2,5,29]$.

\subsection{Genetics and Pathogenesis}

The genetic origin of BSCs has not been fully clarified yet [5]. Although these tumors share histologic features of both BCCs and SCCs, the exact gene mutations that lead to their formation is still a matter of controversy $[5,30]$. On the other hand, the molecular background of BCC and SCC has been thoroughly studied. BCC derives from the over activation of the sonic hedgehog $(\mathrm{HH})$ pathway which inhibits a transmembrane protein called PTCH or activates a transmembrane protein called SMO [31,32]. Other genetic drivers of BCC include PTEN, MYCN, PPP6C, GRIN2A, GLI1, CSMD3, DCC, PREX2, and APC $[30,33,34]$. SCC is characterized by a greater variety of gene mutations which include mutations in HRAS and disruptions of the TGFBR1, TGFBR2, NOTCH1, and NOTCH2 genes as well as additional mutations in CASP8, CDKN2A, NOTCH3, KRAS, 
NRAS, PDK1, BAP1, AJUBA, KMT2D, MYH9, TRAF3, NSD1, CDH1, and TP63 [30,35-38]. A recent, very interesting study by Chiang tried to define the genomic alterations that characterize BSC by using the targeted sequencing of 1641 cancer genes from 20 BSCs, whole exome sequencing from $16 \mathrm{BCCs}$, and a mixture of previously published wholeexome and whole-genome datasets from 52 SCCs [30-39]. According to the findings of this study, the majority of BSCs had underlying PTCH1 and SMO mutations in addition to mutations in other known BCC drivers such as MYCN, PPP6C, GRIN2A, CSMD3, DCC, PREX2, APC, PTEN, and PIK3CA [30]. These data support the theory that the $\mathrm{HH}$ signaling pathway is the initial driver of BSC and that this tumor probably originates as a BCC that partially squamatizes through the accumulation of ARID1A mutations and RAS/MAPK pathway activation $[30,39]$. The most frequent gene mutations that characterize BCCs, SCCs, and BSCs are shown in Table 1.

Table 1. The most frequent gene mutations that characterize BCCs, SCCs and BSCs.

\begin{tabular}{ccc}
\hline BCCs & SCCs & BSCs \\
\hline PTCH & HRAS & PTCH \\
\hline SMO & TGFBR1 & SMO \\
\hline PTEN & TGFBR2 & MYCN \\
\hline MYCN & NOTCH1 & PPP6C \\
\hline PPP6C & NOTCH2 & GRIN2A \\
\hline GRIN2A & CASP8 & CSMD3 \\
\hline GLI1 & CDKN2A & DCC \\
\hline CSMD3 & NOTCH3 & PREX2 \\
\hline DCC & KRAS & PPC \\
\hline PREX2 & NRAS & PIK3CA \\
\hline APC & PDK1 & ARIDIA \\
\hline & BAP1 & \\
\hline & AJUBA & \\
\hline & KMT2D & \\
\hline & CDH1 & \\
\hline
\end{tabular}

\subsection{Biologic Behavior and Prognosis}

According to many authors, in opposition to BCC, BSC is characterized by a more aggressive biologic behavior that is almost equal to that of SCC $[2,5,18,25,40]$. This "aggressiveness" is defined as a more dynamic topical growth of the tumor, as well as a greater potential for recurrences and metastases. As a consequence, the latter characteristics are associated with a worse prognosis as compared to the classic BCC [2,5].

Indeed, a relatively recent study by Zhu et al. including 19 patients with metastatic BSCs suggested an intermediate prognosis between that of BCC and SCC but more favorable than previous assumptions [40]. Volkestein et al. reported that the local recurrence rate of BSC - after wide surgical excision - may reach $45 \%$, which is almost double that of BCC and SCC [18]. In another study, in which the physicians applied Mohs' micrographic surgery, the topical recurrence rate for BSC decreased to 4-9\%, but remained higher than BCC $(0.64 \%)$ and SCC $(1.2 \%)$ [2,14,41,42]. Martin et al. concluded that based on their analysis, the most important predictive factors of topical recurrence for BSCs were male sex, positive surgical margins, lymphatic, and perineural invasion [17]. The metastatic potential of BSC ranges between 4 and $8.4 \%$, which is closer to that of SCC [2,41]. A recent study by Ciążyńska et al. reported that $40 \%$ of patients diagnosed with BSC had a second skin neoplasm. This percentage is significantly higher to the corresponding $23 \%$ reported with other non-melanoma skin cancers (NMSCs) and multiple lesions [7]. In this context, 
they concluded that BSC patients are more prone to the development of new primary skin cancers and for this reason, they should be closely monitored [7].

\subsection{Therapeutic Options and Management of BSC}

To date, there are no established, standard therapeutic guidelines for the treatment of BSCs. The rarity of these tumors along with the absence of robust literature data on the subject is the most reasonable explanation for this situation. Nevertheless, several treatment options have been applied with a variety of outcomes. Superficial methods such as curettage and electrodesiccation have been used in the past but are not considered first line treatment due to their high recurrence rate.

\subsubsection{Wide Surgical Excision}

Although a very high recurrence rate, reaching $45 \%$, has been reported after wide surgical excision, this method remains a first line treatment choice for many authors $[2,5,12$, $16-18,20,21,24,43]$. Furthermore, it is suggested that surgical excision should be followed by the evaluation of a lymph node and distant metastases, and of course, close clinical follow up for recurrence and metastasis $[2,6,17]$.

\subsubsection{Mohs' Micrographic Surgery (MMS)}

Based on the results of recent studies, MMS is considered the optimal surgical option for BSCs, since it is linked to lower recurrence rates compared to the wide surgical excision $[17,24,25,44,45]$. Analytically, Skaria et al. reported an 8.9\% recurrence rate with MMS that is much lower than the $45 \%$ observed with wide surgical excision, but significantly higher when compared with the recurrence rates reported for BCCs and SCCs [44]. Allen et al. achieved an even lower recurrence rate (4.9\%) [45]. However, according to Oldbury et al., there are several practical and financial issues to be addressed in order to officially support MMS as the first-line treatment of choice for BSCs: (a) inability to pre-operatively choose the right candidates for MMS (i.e., clinical diagnosis of BSC instead of BCC) in everyday clinical practice; (b) higher cost of MMS compared to surgical excision; (c) more time-consuming process; and (d) non-applicable in many centers worldwide [12].

\subsubsection{Sentinel Lymph Node Biopsy (SLNB)}

SLNB has been suggested by some authors as part of the management of BSC. However, there is open controversy regarding whether SLNB should be offered in BSCs for the early diagnosis of occult nodal metastasis, staging and treatment of subclinical node disease $[17,27]$. Kakagia et al., in a prospective study with 142 patients with BSC, concluded that tumor size $>2 \mathrm{~cm}$ in addition to lymphatic and perineural invasion are significant determinants of SLN micrometastasis [46]. In the absence of palpable lymphadenopathy, wide resection and SLNB with long-term follow up is highly recommended in these patients [46]. However, a possible "preventive benefit" of early SLNB for the nodal spread and distant metastasis needs further prospective controlled studies, with a longer follow-up period, in order to be confirmed [46].

\subsubsection{Radiotherapy-Chemotherapy}

Adjuvant radiotherapy has been proposed by several authors for BSC, in the scenario of positive surgical margins and the inability to re-excise the tumor in order to achieve them, or in cases with local lymph node metastasis $[2,12,17,47]$. Although there are currently no reports in the literature about the use of radiotherapy in BSCs, some authors, based on their experience with aggressive and/or metastatic BCCs, suggest that treatment with radiotherapy either alone or in combination with surgery may be an appropriate option for the management of BSC, if standard surgical excision or MMS is not possible [12,48]. In a few cases of metastatic BSCs in the literature, palliative chemotherapy has been used (adriamycine, cisplatine) [11]. 


\subsubsection{New Emerging Therapies}

Vismodegib, a Hedgehog pathway inhibitor, is approved for the treatment of adults with metastatic BCC, or with locally advanced BCC that has recurred after surgery, or adults who are not candidates for surgery or radiation [31]. According to the available literature data, the risk of SCC development in individuals treated with vismodegib is a matter of controversy [49-51]. Taking into consideration the fact that BSC pathologically displays features of both BCC and SCC, treatment with vismodegib might bear the risk of the progression of the SCC component of the tumor. Indeed, reports of SCCs developing in patients under vismodegib have been published and a case-control study with 180 patients found an increased risk of SCC in patients under treatment with vismodegib [49]. On the other hand, the largest published cohort study with 1675 patients suggested that vismodegib is not associated with an increased risk of SCC while a systematic and a narrative review of the literature concluded that the existing evidence does not justify an association between vismodegib and SCC formation [31,51,52]. Moreover, there are three very recent case reports including four patients in total which provide preliminary evidence that vismodegib might be effective for difficult-to-treat BSC (Table 2) [53-55]. In all of them, the lesions did not "transform" into purely squamous tumors but in contrast they completely remitted and in two cases the remission was maintained for a very long period of time [53-55]. Although the effect of vismodegib on BSC treatment definitely requires further investigation in larger controlled studies, it could prove to be a future solution for locally advanced BSCs despite the presence of a squamous component in the tumors.

Table 2. Studies which showed a complete response of locally advanced basosquamous carcinoma with vismodegib.

\begin{tabular}{cccc}
\hline Source & Study Design & Number of Patients & Results \\
\hline McGrane J. et al. [53] & Case report & 1 & Marked improvement, stable after 28 months \\
\hline Apalla Z. et al. [54] & Case series & 2 & $\begin{array}{c}\text { Complete clinical response with long-term } \\
\text { follow up (12 and 18 months, respectively }\end{array}$ \\
\hline $\begin{array}{c}\text { Sahuquillo-Torralba A. et al. } \\
\text { [55] }\end{array}$ & Case report & 1 & $\begin{array}{c}\text { Complete } \\
\text { response after 7 months }\end{array}$ \\
\hline
\end{tabular}

Other treatments options such as the PD-L1 inhibitors pebrolizumab and cepilumab have been used for the treatment of advanced-metastatic BCCs and SCCs but still there are no literature data for their use in advanced BSC [56].

\section{Conclusions}

BSC remains a controversial entity, which belongs to the group of NMSCs, sharing characteristics of both BCC and SCC. The differential diagnosis between a BSC and a BCC cannot be made on the grounds of clinical examination. On the other hand, dermoscopy could be more helpful in the diagnosis by revealing features of both components (BCC, SCC) that are otherwise unrecognizable to the naked eye. Histology is the gold standard of diagnosis. Early recognition and correct histologic classification contribute to the optimization of the management of the tumor. Deep incisional biopsies and immunohistochemical techniques (Ber-EP4 staining) facilitate correct diagnosis. In the absence of standardized treatment protocols for BSC, prospective studies comparing various treatment options are needed, in order to reach a consensus regarding ideal management. Surgical treatments, including wide excision and Mohs' micrographic surgery, remain the treatments of choice for most clinicians. The addition of SLNB, radiation therapy, and imaging monitoring in suspicious cases (tumor size $>2 \mathrm{~cm}$, perineural and lymphatic invasion) remain matters of controversy. Radiotherapy could have a supportive role, postoperatively, when re-excision is not possible or not allowed by the patient. Finally, a new treatment prospective such as vismodegib must be thoroughly investigated, with large controlled trials, since it may offer an alternative solution to irresectable or difficult-to-treat locally advanced cases of BSC. 
Author Contributions: Conceptualization, E.L., Z.A.; supervision, E.L., Z.A.; review and editing of the draft, E.L., Z.A., C.F.; investigation of the review, C.F., Z.A.; writing-original draft preparation, C.F. All authors have read and agreed to the published version of the manuscript.

Funding: This research received no external funding.

Conflicts of Interest: The authors declare no conflict of interest.

\section{References}

1. De Stefano, A.; Dispenza, F.; Petrucci, A.G.; Citraro, L.; Croce, A. Features of biopsy in diagnosis of metatypical basal cell carcinoma (basosquamous carcinoma) of head and neck. Otolaryngol. Pol. 2012, 66, 419-423. [CrossRef]

2. Tan, C.Z.; Rieger, K.E.; Sarin, K.Y. Basosquamous carcinoma: Controversy, advances, and future directions. Dermatol. Surg. 2017, 43, 23-31. [CrossRef]

3. MacCormac, H. The relation of rodent ulcer to squamous cell carcinoma of the skin. Arch. Middlesex. Hosp. 1910, 19, 172-183. [CrossRef]

4. Hamilton, M. Basal squamous cell epithelioma. Arch. Dermatol. Syph. 1928, 18, 50-73. [CrossRef]

5. Garcia, C.; Poletti, E.; Crowson, A.N. Basosquamous carcinoma. J. Am. Acad. Dermatol. 2009, 60, 137-143. [CrossRef]

6. Bowman, P.H.; Ratz, J.L.; Knoepp, T.G.; Barnes, C.J.; Finlay, R.E. Basosquamous carcinoma. Dermatol. Surg. 2003, 29, 830-832. [CrossRef] [PubMed]

7. Ciążyńska, M.; Sławińska, M.; Kamińska-Winciorek, G.; Lange, D.; Lewandowski, B.; Reich, A.; Pabianek, M.; Szczepaniak, K.; Hankiewicz, A.; Ułańska, M.; et al. Clinical and epidemiological analysis of basosquamous carcinoma: Results of the multicenter study. Sci. Rep. 2020, 10,1-8. [CrossRef]

8. Burston, J.; Clay, R.D. THE PROBLEMS OF HISTOLOGICAL DIAGNOSIS IN BASO-SQUAMOUS CELL CARCINOMA OF THE SKIN. J. Clin. Pathol. 1959, 12, 73-79. [CrossRef]

9. de Faria, J. Basal cell carcinoma of the skin with areas of squamous cell carcinoma: A basosquamous cell carcinoma? J. Clin. Pathol. 1985, 38, 1273-1277. [CrossRef]

10. Tarallo, M.; Cigna, E.; Frati, R.; Delfino, S.; Innocenzi, D.; Fama, U.; Corbianco, A.; Scuderi, N. Metatypical basal cell carcinoma: A clinical review. J. Exp. Clin. Cancer Res. 2008, 27, 65. [CrossRef] [PubMed]

11. Shukla, S.; Khachemoune, A. Reappraising basosquamous carcinoma: A summary of histologic features, diagnosis, and treatment. Arch. Dermatol. Res. 2020, 312, 605-609. [CrossRef]

12. Oldbury, J.W.; Wain, R.; Abas, S.; Dobson, C.M.; Iyer, S.S. Basosquamous Carcinoma: A Single Centre Clinicopathological Evaluation and Proposal of an Evidence-Based Protocol. J. Ski. Cancer 2018, 2018, 1-7. [CrossRef]

13. LeBoit, P.E.; International Agency for Research on Cancer; World Health Organization; International Academy of Pathology; European Organization for Research on Treatment of Cancer; UniversitätsSpital Zürich. Pathology and Genetics of Skin Tumours; IARC Press: Lyon, France, 2006.

14. Wermker, K.; Roknic, N.; Goessling, K.; Klein, M.; Schulze, H.-J.; Hallermann, C. Basosquamous Carcinoma of the Head and Neck: Clinical and Histologic Characteristics and Their Impact on Disease Progression. Neoplasia 2015, 17, 301-305. [CrossRef]

15. Gualdi, G.; Soglia, S.; Fusano, M.; Monari, P.; Giuliani, F.; Porreca, A.; Di Nicola, M.; Calzavara-Pinton, P.; Amerio, P. Characterization of Basosquamous Carcinoma. A distinct type of keratinizing tumour. Acta Derm. Venereol. 2021, 101, adv00353. [CrossRef] [PubMed]

16. Schuller, D.E.; Berg, J.W.; Sherman, G.; Krause, C.J. Cutaneous Basosquamous Carcinoma of the Head and Neck: A Comparative Analysis. Otolaryngol. Neck Surg. 1979, 87, 420-427. [CrossRef]

17. Martin, R.C.; Edwards, M.J.; Cawte, T.G.; Sewell, C.L.; McMasters, K.M. Basosquamous carcinoma: Analysis of prognostic factors influencing recurrence. Cancer 2000, 88, 1365-1369. [CrossRef]

18. Volkenstein, S.; Wohlschlaeger, J.; Liebau, J.; Arens, A.; Lehnerdt, G.; Jahnke, K.; Neumann, A. Basosquamous carcinoma-A rare but aggressive skin malignancy. J. Plast. Reconstr. Aesthetic Surg. 2010, 63, e304-e306. [CrossRef] [PubMed]

19. Borel, D.M. Cutaneous basosquamous carcinoma. Review of the literature and report of 35 cases. Arch. Pathol. 1973, 95, $293-297$. [PubMed]

20. Mougel, F.; Kanitakis, J.; Faure, M.; Euvrard, S. Basosquamous cell carcinoma in organ transplant patients: A clinicopathologic study. J. Am. Acad. Dermatol. 2012, 66, e151-e157. [CrossRef]

21. Betti, R.; Crosti, C.; Ghiozzi, S.; Cerri, A.; Moneghini, L.; Menni, S. Basosquamous cell carcinoma: A survey of 76 patients and a comparative analysis of basal cell carcinomas and squamous cell carcinomas. Eur. J. Dermatol. EJD 2013, 23, 83-86. [CrossRef]

22. Giacomel, J.; Lallas, A.; Argenziano, G.; Reggiani, C.; Piana, S.; Apalla, Z.; Ferrara, G.; Moscarella, E.; Longo, C.; Zalaudek, I. Dermoscopy of basosquamous carcinoma. Br. J. Dermatol. 2013, 169, 358-364. [CrossRef] [PubMed]

23. Akay, B.N.; Saral, S.; Heper, A.O.; Erdem, C.; Rosendahl, C. Basosquamous carcinoma: Dermoscopic clues to diagnosis. J. Dermatol. 2016, 44, 127-134. [CrossRef] [PubMed]

24. Leibovitch, I.; Huilgol, S.C.; Selva, D.; Richards, S.; Paver, R. Basosquamous carcinoma: Treatment with Mohs micrographic surgery. Cancer 2005, 104, 170-175. [CrossRef] [PubMed]

25. Costantino, D.; Lowe, L.; Brown, D.L. Basosquamous carcinoma—an under-recognized, high-risk cutaneous neoplasm: Case study and review of the literature. J. Plast. Reconstr. Aesthetic Surg. 2006, 59, 424-428. [CrossRef] 
26. Anand, R.L.; Collins, D.; Chapman, A. Basosquamous carcinoma: Appearance and reality. Oxf. Med. Case Rep. 2017, 2017, omw095. [CrossRef]

27. Jankovic, I.; Kovacevic, P.; Visnjic, M.; Jankovic, D.; Binic, I.; Jankovic, A.; Ilic, I. Application of sentinel lymph node biopsy in cutaneous basosquamous carcinoma. Ann. Dermatol. 2011, 23 Suppl. 1, S123-S126. [CrossRef]

28. Malloney, M.L. What is basosquamous carcinoma? Dermatol. Surg. 2000, 26, 505-506. [CrossRef]

29. Jones, M.S.; Helm, K.F.; Maloney, M.E. The Immunohistochemical Characteristics of the Basosquamous Cell Carcinoma. Dermatol. Surg. 1997, 23, 181-184. [CrossRef]

30. Chiang, A.; Tan, C.Z.; Kuonen, F.; Hodgkinson, L.M.; Chiang, F.; Cho, R.J.; South, A.P.; Tang, J.Y.; Chang, A.L.S.; Rieger, K.E. Genetic mutations underlying phenotypic plasticity in basosquamous carcinoma. J. Investig. Dermatol. 2019, 139, 2263-2271.e5. [CrossRef]

31. Apalla, Z.; Papageorgiou, C.; Lallas, A.; Sotiriou, E.; Lazaridou, E.; Vakirlis, E.; Kyrgidis, A.; Ioannides, D. Spotlight on vismodegib in the treatment of basal cell carcinoma: An evidence-based review of its place in therapy. Clin. Cosmet. Investig. Dermatol. 2017, ume 10, 171-177. [CrossRef]

32. Marzuka, A.G.; Book, S.E. Basal Cell Carcinoma: Pathogenesis, Epidemiology, Clinical Features, Diagnosis, Histopathology, and Management. Yale J. Boil. Med. 2015, 88, 167-179.

33. Bonilla, X.; Parmentier, L.; King, B.; Bezrukov, F.; Kaya, G.; Zoete, V.; Seplyarskiy, V.B.; Sharpe, H.J.; McKee, T.; Letourneau, A.; et al. Genomic analysis identifies new drivers and progression pathways in skin basal cell carcinoma. Nat. Genet. 2016, 48, 398-406. [CrossRef] [PubMed]

34. Jayaraman, S.S.; Rayhan, D.J.; Hazany, S.; Kolodney, M.S. Mutational landscape of basal cell carcinomas by whole-exome sequencing. J. Invest. Dermatol. 2014, 134, 213-220. [CrossRef] [PubMed]

35. Cammareri, P.; Rose, A.M.; Vincent, D.F.; Wang, J.; Nagano, A.; Libertini, S.; Ridgway, R.A.; Athineos, D.; Coates, P.J.; McHugh, A.; et al. Inactivation of TGFbeta receptors in stem cells drives cutaneous squamous cell carcinoma. Nat. Commun. 2016, 7, 12493. [CrossRef]

36. South, A.P.; Purdie, K.J.; Watt, S.A.; Haldenby, S.; Breems, N.Y.D.; Dimon, M.; Arron, S.; Kluk, M.J.; Aster, J.C.; McHugh, A.; et al. NOTCH1 Mutations Occur Early during Cutaneous Squamous Cell Carcinogenesis. J. Investig. Dermatol. 2014, 134, $2630-2638$. [CrossRef] [PubMed]

37. Pickering, C.R.; Zhou, J.H.; Lee, J.J.; Drummond, J.A.; Peng, S.A.; Saade, R.E.; Tsai, K.Y.; Curry, J.L.; Tetzlaff, M.T.; Lai, S.Y.; et al. Mutational Landscape of Aggressive Cutaneous Squamous Cell Carcinoma. Clin. Cancer Res. 2014, 20, 6582-6592. [CrossRef] [PubMed]

38. Schwaederle, M.; Elkin, S.K.; Tomson, B.N.; Carter, J.L.; Kurzrock, R. Squamousness: Next-generation sequencing reveals shared molecular features across squamous tumor types. Cell Cycle 2015, 14, 2355-2361. [CrossRef] [PubMed]

39. Tarapore, E.; Atwood, S.X. Defining the genetics of Basoaquamous Carcinoma. J. Invest. Dermatol. 2019, 139, 2258-2260. [CrossRef] [PubMed]

40. Zhu, G.A.; Danial, C.; Liu, A.; Li, S.; Chang, A.L.S. Overall and progression-free survival in metastatic basosquamous cancer: A case series. J. Am. Acad. Dermatol. 2014, 70, 1145-1146. [CrossRef]

41. Alam, M.; Desai, S.; Nodzenski, M.; Dubina, M.; Kim, N.; Martini, M.; Fife, D.; Reid, D.; Pirigyi, M.; Poon, E.; et al. Active ascertainment of recurrence rate after treatment of primary basal cell carcinoma (BCC). J. Am. Acad. Dermatol. 2015, 73, 323-325. [CrossRef]

42. Belkin, D.; Carucci, J.A. Mohs Surgery for Squamous Cell Carcinoma. Dermatol. Clin. 2011, 29, 161-174. [CrossRef] [PubMed]

43. Kececi, Y.; Argon, A.; Kebat, T.; Sir, E.; Gungor, M.; Vardar, E. Basosquamous carcinoma: Is it an aggressive tumor? J. Plas. Surg. Hand Surg. 2015, 49, 107-111. [CrossRef]

44. Skaria, A. Recurrence of Basosquamous Carcinoma after Mohs Micrographic Surgery. Dermatology 2010, 221, 352-355. [CrossRef]

45. Allen, K.J.; Cappel, M.A.; Killian, J.M.; Brewer, J.D. Basosquamous carcinoma and metatypical basal cell carcinoma: A review of treatment with Mohs micrographic surgery. Int. J. Dermatol. 2014, 53, 1395-1403. [CrossRef]

46. Kagakia, D.; Zapandioti, P.; Tryspiannis, G.; Grekou, A.; Tsoutsos, D. Sentinel lymph node metastasis in primary cutaneous basosquamous carcinoma. A cross-sectional study. J. Surg. Oncol. 2018, 117, 1752-1758. [CrossRef] [PubMed]

47. Deganello, A.; Gitti, G.; Struijs, B.; Paiar, F.; Gallo, O. Palliative combined treatment for unresectable cutaneous basosquamous cell carcinoma of the head and neck. Acta Otorhinolaryngol. Ital. 2013, 33, 353-356. [PubMed]

48. Farmer, E.R.; Helwig, E.B. Metastatic basal cell carcinoma: A clinicopathologic study of seventeen cases. Cancer 1980, 46, 748-757. [CrossRef]

49. Mohan, S.V.; Chang, J.; Li, S.; Henry, S.; Wood, D.J.; Chang, A.L.S. Increased risk of cutaneous squamous cell carcinoma after vismodegib therapy for basal cell carcinoma. JAMA Dermatol. 2016, 152, 527-532. [CrossRef] [PubMed]

50. Puig, S.; Sampogna, F.; Tejera-Vaquerizo, A. Study on the risk of cutaneous squamous cell carcinoma after vismodegib therapy for basal cell carcinoma: Not a case-control study. JAMA Dermatol. 2016, 152, 1172-1173. [CrossRef] [PubMed]

51. Bhutani, T.; Abrouk, M.; Sima, C.S.; Sadetsky, N.; Hou, J.; Caro, I.; Chren, M.-M.; Arron, S. Risk of cutaneous squamous cell carcinoma after treatment of basal cell carcinoma with vismodegib. J. Am. Acad. Dermatol. 2017, 77, 713-718. [CrossRef] [PubMed]

52. Jacobsen, A.A.; Aldahan, A.S.; Hughes, O.B.; Shah, V.V.; Strasswimmer, J. Hedgehog pathway inhibitor therapy for locally advanced and metastatic basal cell carcinoma: A systematic review and pooled analysis of interventional studies. JAMA Dermatol. 2016, 152, 816-824. [CrossRef] 
53. McGrane, J.; Carswell, S.; Talbot, T. Metastatic spinal cord compression from basal cell carcinoma of the skin treated with surgical decompression and vismodegib: Case report and review of Hedgehog signalling pathway inhibition in advanced basal cell carcinoma. Clin. Exp. Dermatol. 2017, 42, 80-83. [CrossRef] [PubMed]

54. Apalla, Z.; Giakouvis, V.; Gavros, Z.; Lazaridou, E.; Sotiriou, E.; Bobos, M.; Vakirlis, E.; Ioannides, D.; Lallas, A. Complete response of locally advanced basosquamous carcinoma to vismodegib in two patients. Eur. J. Dermatol. EJD 2019, $29,102-104$. [PubMed]

55. Sahuquillo-Torralba, A.; Llavador-Ros, M.; Caballero-Daroqui, J.; Botella-Estrada, R. Complete response of a locally advanced basosquamous carcinoma with vismodegib treatment. Indian J. Dermatol. Venereol. Leprol. 2019, 85, 549-552. [CrossRef]

56. Shalhout, S.Z.; Emerick, K.S.; Kaufman, H.L.; Miller, D.M. Immunotherapy for Non-melanoma Skin Cancer. Curr. Oncol. Rep. 2021, 23, 1-10. [CrossRef] [PubMed] 